\title{
Zeker meten. Zeker weten?
}

Citation for published version (APA):

Prins, M. H. (2002). Zeker meten. Zeker weten? Maastricht University. https://doi.org/10.26481/spe.20020614mp

Document status and date:

Published: 14/06/2002

DOI:

10.26481/spe.20020614mp

Document Version:

Publisher's PDF, also known as Version of record

\section{Please check the document version of this publication:}

- A submitted manuscript is the version of the article upon submission and before peer-review. There can be important differences between the submitted version and the official published version of record.

People interested in the research are advised to contact the author for the final version of the publication, or visit the DOI to the publisher's website.

- The final author version and the galley proof are versions of the publication after peer review.

- The final published version features the final layout of the paper including the volume, issue and page numbers.

Link to publication

\footnotetext{
General rights rights.

- You may freely distribute the URL identifying the publication in the public portal. please follow below link for the End User Agreement:

www.umlib.nl/taverne-license

Take down policy

If you believe that this document breaches copyright please contact us at:

repository@maastrichtuniversity.nl

providing details and we will investigate your claim.
}

Copyright and moral rights for the publications made accessible in the public portal are retained by the authors and/or other copyright owners and it is a condition of accessing publications that users recognise and abide by the legal requirements associated with these

- Users may download and print one copy of any publication from the public portal for the purpose of private study or research.

- You may not further distribute the material or use it for any profit-making activity or commercial gain

If the publication is distributed under the terms of Article $25 \mathrm{fa}$ of the Dutch Copyright Act, indicated by the "Taverne" license above, 


\section{Zeker meten. Zeker weten?}

Inaugurele redes 



\section{Zeker meten. Zeker weten? \\ Klinische Epidemiologie in de Praktijk}

Rede uitgesproken bij de aanvaarding van hel ambt van Hoogleraar Klinische Epidemiologie aan de Faculteit der Geneeskunde van de Universiteit Maastricht op vrijdag 14 juni 2002 door

Dr. M.H. Prins 
Mijnheer de Rector Magnificus,

Zeer geachte dames en heren.

Meten is weten, maar in de situatie van patientgebonden onderzoek is het vertalen van de meetresultaten naar de klinische praktijk meer dan een zaak van getallen alleen en heeft evenzeer te maken met de klinische situative, de aard en opzet van het betreffende onderzoek als met de resultaten erwan.

Vandaag zal ik met het uitspreken van deze rede in het openbar het ambt aianvaarden van hoogleraar Klinische Epidemiologie aan de Faculteit der Geneeskunde.

\section{Algemene plaatsbepaling}

Methodologie van patiëntgebonden onderzoek, met andere woorden 'Klinische Epidemiologie', is gedurende de laatste jaren geaccepteerd geraakt als klinische discipline, welke onderwezen dient te worden aan studenten geneeskunde en door artsen en specialister gebruikt kan worden om de hun aangeboden wetenschappelijke informatie te graderen op kwaliteit. In niet onbelangrijke mate is dit gestimuleerd door het omarmen wan het principe van "evidence based medicine' of 'evidence based practice', hoe gebrekkig deze termen ook zijn, door grote delen wan de academische en algemene medische gemeenschap. Redenen woor het omarmen van dit principe kunnen gevarieerd zijn. Bij wetenschappelijk opgeleide geneeskundigen zal het echter moeten gaan om het verlangen op een wetenschappelijk verantwoorde wijze het diagnostisch en therapeutisch beleid bij zijn of haar patient vast te stellen. Met nadruk zou ik er op willen wijzen dat de oorsprong van het kritisch kijken naar de wetenschappelijke bewijslast, welke ten grondslag ligt aan ons medisch handelen, bij ons, bij medici ligt en niet bij politici, beleidsmakers of epidemiologen. Met name de rol wan de groep internisten werkzaam in de tachtiger jaren wan de vorige eeuw in Hamilton, Ontario, Canada dient hierin genoemd en geroend te worden [1]. Niet blindelings vertrouwen op wat het gezag - de docent of opleider - ons voorschotelt, maar kritisch de achtergronden van de medische adviezen bestuderen, is iets dat ook wel zeer past bij het prototypische beeld van het karakter van de Nederlandse student en assistent uit de jaren tachtig van de vorige eeuw. Tevens is 
'evidence based practice' een principe, dat, hoe contra-intuitief dit ook moge klinken, de patient centraal stelt. Namelijk, iedere medische handeling, hoe onschuldig die ook mag liken, zoals de opmerking "we hebben bij toeval een factor V Leiden mutatie bij u gevonden; u mag wel uitkijken met de pil" heeft potentieel negatieve gevolgen [2]. Als er geen goede basis is voor het handelen; met andere woorden: indien er geen 'baat' is. blijven slechts de averechtse effecten over en ondervindt de patient mogelijk een nadeel van dit handelen. Aan de andere kant dient te worden geconstateerd dat het almhangen van 'evidence base medicine' soms leidt tot onterecht nihilisme. Als lets niet bewezen effectief is, conform de hoogrte eisen, "dan kunnen we niets doen". Dit is soms onterecht. Niet bewezen effectief, is niet gelik aan niet effectief. Bill gebrek aan gegevens in de hoogste categorie van bewijskracht en -last, moeten we soms bereid zijn terug te vallen op zwakkere vormen van bewijs. Tevens zal de academische gemeenschap het opmerken van dit soort situaties als een uitdaging moeten zien om, binnen de beperkingen wan patiëntenaantallen. medische ethiek en de beperkingen die vaak woortwloeien uit de klinische situaties, de onderliggende bewijskracht en - last voor dit soort behandelingen te verbeteren. De overheid zou zulke pogingen ruimhartiger moeten steumen. Het bezuinigen op patiëntgebonden medisch wetenschappelijk onderzoek door de overheid getuigt dan ook niet van visie.

Gezien in het licht van dit wetenschappelijk verlangen patiënten een zo optimaal mogelijk diagnostisch-therapeutisch traject aan te bieden "is het triest dat het argument "evidence based medicine' bij beleidsmakers thans voornamelijk wordt gebruikt om dure methoden van diagnostiek en behandeling uit te sluiten van vergoeding. Dit 'duur' kan zowel slaan op de kosten van een behandeling voor een enkele patient als op de totale kosten van een goedkopere behandeling, waarvoor vele patiënten in aanmerking zouden kumnen komen. Bij 'evidence based practice' staat het belang van de patiënt centraal, niet het belang van de overheid of ziektekostenverzekeraar. Het alloceren van geiden in de gezondheidszorg op rationele gronden heeft slechts ten dele te maken met 'evidence based medicine? , doch veel meer met het stellen van prioriteiten.

Ook voor universiteiten betekent 'evidence based medicine' een moodzaak tot herziening van structuren. Basaal onderzoek kan de basis zijn voor vernieuwende diagnostische en therapeutische opties. Het zou echter onverstandig zijn om hier als universiteit te stoppen. Teneinde de taken naar de bevolking toe optimaal wit te woeren zullen deze opties 
adequat in patientgebonden onderzoek geevalueerd dienen te worden, zodat ze niet als losse, veelbelovende flodders of ongenthte, doch vaak toch nog gevaarlike ongeleide projectielen op de medische stand en de patiënt worden losgelaten, maar van bewezen waarde zijn. Een dergelijk inzicht heeft voor de universitaire situatie vergaande consequenties. Zij dwingt niet alleen tot samenwerking tussen klinische en niet-klinische afdelingen, maar ook tot het in samenspraak tussen deze afdelingen formuleren van strategieen van ontwikkeling. De universiteit en het academische ziekenhuis zullen moeten samenwerken en inzetten op trajecten, waarbij ideeën, ontwikkeld in het laboratorium van preklinische en klinische afdelingen via gedegen patientgebonden onderzoek, gevolgd door implementatie, op de medische kaart worden gezet. Het zich alleen spiegelen aan preklinische successen of aan successen met patiëntgebonden onderzoek is niet meer voldoende. Maatschappelijk relevante zaken, zoals implementatie in de algemene gezondheidszorg horen ook bij het spectrum van aandachtsgebieden.

In het vervolg van deze rede will ik ingaan op concepten van meten van therapeutische en diagnostische effectiviteit en daarna aanstippen op welke terreinen van onderzoek naar therapeutische en diagnostische effectiviteit er ontwikkelingen te verwachten zijn die de theoretische onderbouwing en de onderzoekstechnieken van de Klinische Epidemiologie nog dichter zullen laten aansluiten bij de medische praktijk.

\section{Concepten van Meten - Therapie}

Recent werd, naar aanleiding van de discussie rondom thet nut van de bevolkingsscreening op mammacarcinoom, in het weekblad Elsevier. beweerd dat een aantal artikelen omtrent dit onderwerp zodanig moeilijk waren 'dat alleen hoogleraren Methodologie en Epidemiologie deze zouden kunnen begripen' [3]. Als dat zo zou zijn, heeft de Klinische Epidemiologie, het vakgebied dat de ontwikkeling van methoden en technieken voor patientgebonden onderzoek behelst, haar doel gemist. De concepten voor optimale methodologie wan het meten van het effect van een inteventie zijn in essentie uitermate eervoudig en kunnen glashelder worden overgebracht. Het meesterschap zit in de optimale toepassing van de methoden en technieken in relatie tot de betreffende klinische situatie en de beperkingen die daar vaak wit voortwloeien. 
De wetenschappelike vraag dient helder gesteld te worden. De patientenpopulatie wordt geoperationaliseerd middels de in-en exclusie criteria voor participatie in het onderzoek. Hierbij is aandacht voor geaccepteerde criteria, voor het stellen van de diagnose en behandelingsindicatie, wan belang. De te vergelijken behandelingen, of diagnostische strategieën zijn zoveel mogelijk 'state of the art'. Bovendien is de te bestuderen uitkomst klinisch relevant, gedefinieerd en geoperationaliseerd in het onderzoeksprotocol en de gekozen uitkomst heeft bekende en goede meetkarakteristieken. Een dergelijk klinisch valide onderzoek zal kunnen resulteren in een effectmeting die aansluit bij de klinische praktijk. Vervolgens zal het vermijden van vertekening in het meetresultaat door randomisatie. blindering en een adequate analyse een zeker meetresultaat wan het effect of verschill in effect wan de bestudeerde behandelingen geven.

Randomisatie heeft tot doel slechts het toeval te laten beslissen wie welke behandeling krijgt. Hermede wordt het mogelijk, indien aan verdere voorwaarden voldaan wordt, het verschil in effect tussen de behandelingen volledig toe te schriven aan de verschillen tussen de behandelingen. Van randomisatie is sprake, indien op het moment van wragen van een participant om mee te doen aan een onderzoek, noch deze participant, noch de persoon die hem/haar informatie verschaft over het onderzoek, weet welke behandeling de participant uiteindelijk zal krijgen. De participant zal in de medische situatie natuurlijk veelal een patiènt zijn. Het valt te begrijpen dat het uitleggen van de achtergronden van de equipose, welke het uitvoeren van het onderzoek ethisch maakt, een tijdrovend karweil is. Dit is overigens een tijdsinvestering waarmee, bij planning van de activiteiten in het kader van het onderzoek, vaak onvoldoende rekening wordt gehouden.

Blindering heeft tot doel het gedrag van betrokkenen bij de behandeling van de patiënt en uitvoerenden in het onderzoek niet te laten beinvloeden door kennis van de aard van de behandeling en aldus te voorkomen dat de grootte van het gemeten effect beïnwloed wordt. Blindering dient te geschieden op meerdere niveaus. Hierbij dient gedacht te worden aan het niweau van de patient die participeert in het onderzoek, de arts die deze patiênt behandelt ${ }_{\text {i }}$ de klinisch onderzoeker, de persoon welke verantwoordelijk is voor de dataverzameling in de kliniek, de persoon de verantwoordelijk is voor het toekennen van de uitkomststattus, de personen betrokken bij datamanagement en ten slotte de personen verantwoordelijk voor het uitvoeren van de analyse en rapportage. De term 
"dubbelblind" is dan ook verouderd en non-informatief. Artikelen en rap. porten zullen uitgebreider moeten ingaan over de binnen het onderzoek bereikte mate van blindering.

Tenslotte zal het uitvoeren van een adequate analyse aan de hand van een van tevoren opgesteld analyseplan, waarbij de primaire analyse al in het protocol dient te zijn aangeduid, een betrouwbare effectmeting opleveren. Dit analyseplan dient zowel de te gebruiken populatie als de te gebruiken statistische tests voor de analyse te beschijuen. De primaire analyse resulteert in een zogenaamde puntschatting van thet effect. Helaas zit om deze puntschatting van effectiviteit een marge van onzekerheid. De grootte van deze marge hangt sterk af wan het aantal in het onderzoek ingesloten patiënten. Deze marge van onzekerheid kan het gemakkelijkst en best weergegeven worden met een $95 \%$ betrouwbaarheidsinterval. Dit meetresultaat, met de bekende marge van onzekerheid, is de 'evidence', die de basis dient te vormen voor ons medisch handelen.

Vertaling van de 'evidence', de harde getallen, naar de medische praktijk is echter minder eenvoudig. Bij deze vertaling speten vele factoren een rol. Onder andiere valt hierbij te denken aan -verschillen in-kosten, een onderwerp dat ik verder niet zal uitwerken. Andere factoren zijn, en deze opsomming is niet limitatief, -verschillen in- de belasting voor patienten, maar ook voor artsen, beschikbaarheid van apparatuur, benodigde expertise en toekomstige inwesteringen. Een voorbeeld: stel dat adequat uitgevoerd onderzoek heeft aangetoond dat een kuur van een week met cen éénmaal daags oraal toegediend, niet extreem duur, medicijn één mensenleven redt per honderd behandelde patiënten (bijwerkingen in acht genomen). Hier zullen weinig drempels zijn om tot implementatie te komen. Indien echter dit ene mensenleven per honderd behandelde patienten gered wordt door een 8 uur durende, technisch moeilijke, chirurgitische interventie, met een perioperatieve mortaliteit van ongeveer $10 \%$ (welke uiteraard in acht is genomen bij de berekening wan het netto effect), zal de balans wel doorslaan naar de andere zijde en vindt implementatie niet plaats, ondanks de zekerheid van een gemeten effect. Dit geeft tevens aan dat het gepropageerde "number needed to treat", ahoewel informatief, zeker niet zaligmakend is. Een 'number needed to treat' betekent alleen iets in relatie tot de aard en de duur van de behandeling.

In de praktijk liggen de situaties echter veel minder zwart-wit dan in het gegeven voorbeeld. Soms zijn interventies, erg 'goedkoop"; men den- 
ke biyvoorbeeld aan foliumżur en vitamine $B 6$ voor hyperhomocysteinaemie, een risicofactor woor atherosclerotisch vaatijden. Het is aangetoond dal het toedienen van folumzuur en vitamine $B 6$ de biochemische kenmerken van hyperhomocysteïnaemie doen verdwijnen. Echter, eir is geen bewijs dat het ook klinisch beter gaat met deze patiënten. is het bawijzen van effectiviteit hier noodzakelijk of geldt hier: "baat het niet dan schaadt het niet" zelfs niet economisch?[4]. Het is waarschinnlijk dat bif een zeer gering effect, zeg een relatief risico reductie van 2 tot $5 \%$, een dergelike therapie al kosteneffectief is. De omvang en dientengevolge de kosten van een onderzoek in staat om een dergelijk klein effect aam te tonen dan wel uit te sluiten, zullen enorm zin. Wellicht is een dergelijke onderneming dan ook in principe futiel en is het gedogen van een nict op 'evidence' gebaseerde behandeling verstandiger. Overigens geeft het berekenen van het minimale effect, waarbij een behandeling nog kosteneffectief zou zijn, een expliciete mogelijkheid om de minimale grootte van een gerandomiseerd onderzoek, dat de praktijk en dus de implementatie effectief kan beïnloeden, te berekenen.

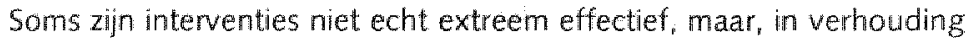
tot de kosten en moeite misschien net wel uitvoerbaar. Ik kan u verzekeren dat pogingen dit effect uit te drukken in kosten en effecten op kwaliteit wan leven, de sleutelwoorden in moderne subsidie aanvragen, wel altijd een nette beschriving wan het gemeten effect kunnen geven, maar lang iniet altijd een sluitend antwoord zullen opleveren ten aanzien van de wenselijkheid en het succesvol zijn van implementatie hiervan. Als voorbeeld zou kunnen dienen de $\mathrm{CBO}$ richtlijn diagnose van longembolie uit 1993. Deze was op goede 'evidence" gebaseerd, doch heeft nimmer volledige implementatie bereikt door voomamelijk praktische en logistieke vereisten $[5,6]$. Dit zijn de andere, minder makkelijk in getal te vangen factoren, die een belangrijke rol spelen bij actuele implementatie. Over het algemeen zal het zo zijn dat nieuwe interventies, die de praktijk vereenvoudigen en minimaal equivalent lijken te zijn, snel geaccepteerd worden. Een woorbeeld hievan is de snelle invering in vele landen van de thuisbehandeling van diepe veneuze trombose met laag moloculair gewichtsheparinen of het vervangen van de invasieve venografie door ultrageluid voor de diagnose van diepe veneuze trombose. Anderzijds zullen interventies die werandering van attitude en praktijkvoering vereisen een veel langzamer patroon van implementatie kennen. Indien dit zeer (kosten)effectieve interventies betreffen, zal de universitaire taak zich 
niet moeten beperken tot het leveren van dit bewijs van effectiviteit, maar zich ook uitstrekken tot het traject van succesvolle implementatie, dit door educatie en voorbeeldfunctie.

\section{Ontwikkelingen in therapeutisch onderzoek}

Er liggen vele urtdagingen voor ons in het therapeutisch onderzoek. Vele. hoog technologische interventies laten zich niet gemakkelijk methodologisch adequaat onderzoeken. Vaak is dit soort interventies, blindering van patient, arts of onderzoeker miet goed mogelijk, terwijl deze juist het individuele effect beoordelen. Creativiteit is dan gewenst en op maat gesneden oplossingen dienen in dit soort gevallen ontwikkeld te worden. Uiteraard is zorg woor blindering op het niveau wan uitkomsttoekenning hier wan het grootste belang. Dit kan heel vaak geregeld worden via 'offline' beoordeling van objectieve tests of zelfs achteraf beoordeling van video-opnames van gedrag.

Tevens kan het zeer moeilijk zijn patienten in te sluiten in klassiek gerandomiseerd onderzoek naar hoogtechnologische interventies. Een patient stemt toe am mee te doen, krijgt vervolgens de klassieke (niet) behandelling toegewezen, maar is wel op de hoogte van het bestaan van een geavanceerde, weliswaar niet gevalideerde, behandeling. Een dergelijk klassiek design leidt tot een moeizame informed consent procedure, daar vele patiënten, ook na uitgebreide witleg van de aard en het doel van het onderzoek, zullen weigeren. Ook kan in dit geval een klassieke onderzoeksopzet leidem tot uitval van deelnemende patiënten uit het onderzoek en cross-over naar de nieuwe behandeling. Het betrouwbaar meten van het effect van deze nieuwe technologie kunnen we dan wel wergeten. Een mogelijk alternatief is het zogenaamde Zelen design of pre-randomisatie. Alleen personen toegewezen aan de nieuwe behandeling worden geïnformeerd en gevraagd mee te doen. Nog afgezien van de medisch, ethische aspecten van een dergelijke opzet is dit niet een algemene oplossing voor het probleem. Ten eerste is dit design uitsluitend mogelijk bij een klinische, gernakkelijk te bepalen, uitkomst (zoals mortaliteit of optreden van myocardinfarct); het is tenslotte op zijn minst vreemd om plotseling kwaliteit van leven te gaan meten of een extra röntgenologische test te doen bij patienten, die niet weten dat ze meedoen aan een onderzoek. Bowendien zal het toepassen van twee soorten behandelingen, zeker in 
combinatie met de mogelijkheden van de huidige informatiemaatschappii", leiden tot cross-over en contaminatie door het uitvoeren van het onderzoek zelf. Met andere woorden: door kennis te nemen van patiën. ten die de nieuwe behandeling krijgen, raken behandelend artsen en ook andere patienten op de hoogte van de nieuwe mogelijkheid en het proces van vertekening van de te meten effectiviteit begint. Eén vorm van randomisatie verdient hier bijzondere aandacht. Het randomiseren naar directe of uitgestelde behandeling met de nieuwe interventie. Deze periode van uitstel kan dan gebrukt worden om een betrouwbare effectschatting te krijgen. Het vragen van patiënten om te participeren in dit soort onderzoek is relatief eenvoudig, immers de nieuwe behandeling is een ieder in het vooruitzicht gesteld. Een nadeel is dat op deze wijze geen langetermijneffecten bestudeerd kunnen worden. Door middel van langdurige follow-up en besliskundige modellering zou dit echter ondervangen kunnen worden.

Een andere mogelijkheid is niet op het niveau van de patient te randomiseren, maar op een hoger niveau. Hiermede worden vooral de eerder genoemde problemen van cross-over en contaminatie voorkomen. Hierbij kan gedacht worden aan randomiseren op het niveau van huisiarts, huisartsengroepspraktijk, ziekenhuisafdeling, ziekenhuis stad, provincie of zelfs land. Het probleem hier is de 'eenheid onder studie" "waarmee in de analyse rekening gehouden zal moeten worden. Een dergelijke vorm van randomiseren is wooral nuttig bij de evaluatie van interventies gericht op preventie op het niveau van de bevolking. Echter, indien het klinisch onderzoek betreft, moet vaak weer op patiëntmiveau toestemming gevraagd worden. Dit leidt tot het grote nadeel van mogelijke selectieve inclusie. Een nadeel dat moet worden afgewogen tegen de potentiële voordelen. In ieder geval zal bij de analyse rekening moeten worden gehouden met de nieuwe eenheid van studie en de mogelijkheid van selectieve participatie. Objectieve uitkomsten, welke makkelijk meetbaar zijn (mortaliteit, klinische events), zijn bij dit soort onderzoeksopzet ideaal. In leder geval zal bij toepassing in klinische situaties zorg moeten worden gedragen voor een complete registratie van potentiële participanten, teneinde selectieve participatie in de analyse te kunnen betrekken.

Eir zijn situaties waar randomisatie echt onmogelik is, zoals bij het vergelijken van interventies met grote logistieke consequenties , binnen een ziekenhuis. Om effectmetingen in dit soort situaties toch mogelijk te maken is gefaseerde invoering met herhaalde voor- en nametingen een 
geschikte methodologie: In afwezigheid van randomisatie zal een consistente grootte en richting vain het gemeten effect toch zekere bewijskracht toegekend kurnen krijgen.

De geschetste mogelijkheden moeten ons er echter niet toe verteiden bij voorbat af te zien van een klassiek gerandomiseerd design. Dit paradigma heeft uit theoretisch oogpunt over het algemeen de beste meeteigenschappen. Slechts indien deze meeteigenschappen negatief beinvloed worden door de klinische en of logistieke omstandigheden is vlucht tot een eenvoudiger oplossing te verdedigen.

Een toenemend aantal gerandomiseerde ondezoeken zullen niet de vragg betreffen "is deze behandeling beter?" mala "is deze nieuwe behandeling even effectief als de huidige standaardbehandeling?" Het nieuwe medicament is dan gemakkelijker in gebruik of geeft minder bijwerkingen of de nieuwe interventie is minder invasief en geeft minder post-interventionele complicaties. Het uitvoeren wan dergelijke 'equivalentie' of "non-inferiority" onderzoeken vraagt enige aanpassingen in methodologie van onderzoek. Uiteraard blift het principe van randomisatie en blindering gehandhaafd, maar met name groepsgroatte overwegingen en analyse vragen een andere benadering. Uiteraard is thet ontbreken van een statistisch aantoonbaar verschil in effect tussen een nieuwe en een standaardbehandeling niet voldoende reden om die nieuwe behandeling als klinisch equivalent te beschouwen. Van tevoren zal op basis van gegevens, beschilkbaar over de standaard behandeling aangegeven moeten worden wat de drempel van toegestaan verlies zal zijn om de nieuwe behandeling als equivalent te beschouwen. Vervolgens is het zaak om de groepsgrootte zodanig te kiezen, dat aangetoond kan worden dat, bij een in werkelijkheid gelijk effect, deze mate van verslechtering niet wordt overschreden. Het is de taak van de medische gemeenschap er voor te waken dat een behandeling slechts als equivallent wordt. geaccepteerd indien een belangrijk verlies van klimisch effect inderdaad is uitgesloten en dat er niet, door repetitief nieuwe behandeling als equiva. lent te accepteren, een verlies van effect optreedt.

Wij zijn een interveniërende maatschappij geworden; het natuurlijk beloop van een ziekte is niet meer te beschrijuen. well het beloop bij de "best mogelijke interventie". Systematische registratie van dit beloop - zeg maar - 'post marketing surveillance' - kan waardevoll zijn voor het herkennen van gebieden waar verbetering van ons medisch handellen nodig is. Vooral moet hierbij aandacht worden besteed aan het geven wan feed. 
back tussen de beroepsgroepen onderling. Moderne informatietechnologie, bijvoorbeeld middels 'elektronische koppeling van bestanden', kan hierbil behulpzaam zijn. Wel zou de overheid dan moeten stimuleren dat dit soort bestanden voor onderzoekers, zonder hoge kosten, te gebruiken zijn.

\section{Concepten van meten-Diagnostiek}

Diagnostiek kan gedefinieerd worden als het verkrijgen van informatie ter ondersteuning van een medische handeling. Dit hoeft niet alleen het stellen van een diagnose te zijn, maar kan ook het stellen van een indicatie voor cen bepaalde vorm van therapie, het bijstellen van een gegeven behandeling (monitoring) of het geven van informatie betreffen. De methodologie wan diagnostiek met het doel een diagnose te stellen is het best ontwikkeld. Consecutieve patiënten, welke verdacht warden van de aandoening van interesse, worden geîncludeerd. Op niet te ver van elkaar gelegen tijdstippen worden de referentiestandaard voor de aandoening van interesse en de nieuwe diagnostische test verricht bij alle geïncludeerde patienten. Beiden worden onafhankelijk van elkaar geïnterpreteerd en vervolgens aan elkaar gerelateerd. De nu verkregen parameters, zoals sensitiviteit, specificiteit, positief en negatief voorspellende waarden geven nu een beeld van de waarde van de nieuwe diagnostische test voor de aandoening van interesse. Met opnieuw rondom de puntschattingen een marge van onzekerheid, uit te drukken met een $95 \%$ betrouwbaarheidsinterval.

Er zijn hier echter meer onzekerheden. Een eerste betreft de referentiestandaard; ook deze heeft, walarschijnlijk net als de nieuwe test, observer variatic en is vaak wel gebruikt als referentiestandaard, maar is niet altijd de 'gouden' standaard. Een nieuwe test, die de potentie heeft beter te zijin dan de referentiestandaard, zal nooit als zodanig herkend kunnen worden in dit type onderzoek. Bovendien is het niet altijd zeker of alle gedetecteerde vormen van ziekte met de referentiestandaard ook daadwerkelijk behandeling en dus detectie behoeven.

Steeds vaker vindt men dan ook voorbeelden van onderzoek waarbij de klinische consequenties van de gebruikte diagnostiek worden vastgelegd. Consecutieve patiènten, verdacht van een bepaalde aandoening, zoals longembolie, worden middels een gestandaardiseerde diagnostische 
strategie geêvalueerd. Alle personen ingesloten in het onderzoek worden een zekere tijd (bijk. 3 tot 6 maanden) gevolgd en hun klinisch beloop wordt in kaart gebracht. De uitikomst van interesse in dit soont onderzoek is dan bijwoorbeeld de incidentie van complicaties ten gevolge vam een gemiste diagnose. Daar bij een redelijk functionerende test en een relatief lage prevalentie van de aandoening bij patienten welke hiervan werdacht worden de frequentie van gemiste zieken laag is stelt dit type onderzoek hoge eisen aan de aantallen te bestuderen patiênten en aan de volledig. heid van follow-up.

Een laatste vorm van onderzoek naar de waarde wan diagnostiek betreft het standaard gerandomiseerde onderzoek. Aan één groep wordt de diagnostische test aangeboden; er wordt behandeld indien ziekte wordt aangetroffen. Aan de andere, de controlegroep, wordt de test niet aangeboden. Vervolgens wordt de mortaliteit in beide groepen bestudeerd. Fraaie voorbeelden hiervan zijn de eerder gerefereerde onderzoeken aan de effectiviteit wan bevalkingsonderzoek op mammacarcinoom. Het gèmeten effect is dan een resultante van de prevalentie van de alandoening, de mate van acceptatie en sensitiviteit van de test en de effectiviteit van de behandeling. Als bijvoorbeeid de prevalentie van de aandoening daalt door aandacht woor en vermindering van risicofactoren of door het uitzeven van personen met het hoogste risico door genetisch familieonderzoek, is de effectiviteit wan zo'n bevolkingsbrede screening weer een groot vraagteken. Wellicht is herhaalde, beslisikundige modellering voor dit soort situaties veel aantrekkelijker dan telkens opnieuw een groots opgezette gerandomiseerd onderzoek, met een minimale duur van 10 tot. 15 jaar, te startem. Een vergelijkbare discussie speelt zich overigens ook af op het gebied van screening naar het coloncarcinoom.

\section{Ontwikkelingen in diagnostisch onderzoek}

In het algemeen kan men stellen dat het dichotome denken en analyseren, op het gebied van onderzoek naar diagnostiek, niet goed aansluit bij de klinische praktijk. Nadat een patiënt zijn terste klachten gepresen. teerd heeft, schieten de clinicus over het algemeen een aantal mogelijke oorzaken van de klachten door het hoofd, de aanvankelijke brede differential diagnose. Door systematische navraag naar het klachtenpatroon en aanvullend lichamelijk onderzoek resteert er dan een lijst met diagno- 
sen, meestal meer dan twee en staat de clinicus voor de taak tests aan te vragent teneinde tot een definitieve diagnose te komen. In contrast hiermee staat zowel de gebrukelijke wijze, waarop diagnostische tests worden geevalueerd in de medische literatuur, als de beschilkbare methodologie voor evaluatie van diagnostische tests. In plaats van een keuze tussen verschillende diagnosen is hier de uitkomst diagnose $X j a$ of nee. Wel is te zien dat in de recente literatuur de term "alternatieve diagnose" steeds vaker opdukt in klinische beslisregels en diagnostische algoritmen. Dit is op zich een primitieve manier om te erkennen dat in het denken van de dokter incerdaad meer speelt dan aan- of afwezig zijn van diagnose $X$. Klassiek is het gebruik van Bayes Theorema om de karakteristieken van een test (sensitiviteit en specificiteit) samen met de vooraf ingeschatte kans op de diagnose om te zetten in een achteraf kans. Deze benadering gaat er van uit dat deze testkarakteristieken een constant gegeven zijn. Het wordt steeds duidelijker dat de testkarakteristieken in sterke mate afhangen van de voorat ingeschatte kans op de diagnose en van resultaten van woorgaande diagnostische tests $[7,8]$. Oftewel: net nu het gebruik van dit theorema begint door te dringen tot de wooruitstrevende clinici, blijkt het achterhaald. Methodologen hadden beter moeten weten voor ze deze "prior odds maal likelihood rate" van de daken schreeuwden. Echter, er zijn mogelijkheden. Uiteraard is, bij een ingeschatte lage vooraf kans, het bestaan van een alternatieve diagnose waarschijnlijker. Het mathematisch uitwerken en het vervolgens pragmatisch interpreteren van deze invloeden van de waarschijnlijkheid van een alternatieve diagnose zou een weg kunnen bieden naar een meer bij de klinische praktijk aansluitende manier van onderzoek naar diagnostiek. Het variëren van de likelihood rate met klinische kenmerken en resultaten van eerdere diagnostiek, pleit overigens tegen de inzet van het standaard logistische model.

Er is naar mijn oordeel, zeker nu er een trend is om de klinische gevolgen wan een diagnostische strategie als bewijslast te accepteren, een grote noodzaak voor een nieuwe tak van diagnostisch onderzoek: de 'post marketing surveillance. Zelts in een recente serie van gezaghebbend auteurs op het gebied van de diagnostische test werd deze fase van diag. mostisch onderzoek niet beschreven [9]. De waarde van een diagnostische test is niet een gegeven van de test zelf, maar athankelijk van de klinische situatie waarin hij wordt toegepast. Door media-aandacht of door locale gewoonten kan het gebeuren dat personen met een bepaalde ziekte in een veel wroeger stadium onder medische aandacht komen. De test die 
goed werkte voor gevorderde stadia van ziekte, zou wel eens andere testkarakteristieken kumnen hebben voor deze vroegere stadia. Dit verschuivend spectrum met gevolgen voor sensitiviteit en specificiteit van een test heef tot gevolg dat het wenselik is ook voor dia gnosische tests een 'post marketing surveillance' programma op te zetten. Een woorbeeld uit de recente praktijk is het gebruik van impedantie plethysmografie voor de diagnose diepe veneuze trombose. Hoewel deze diagnostische test ook naar nu geldende criteria adequat geëvalueerd was en aldus 'evidence based' kon worden ingezet, bleken er toch na een aantal jaren patiënten te zijn bij wie de diagnose diepe weneuze trombose gernist werd $[10,11]$. Door opmerkzaamheid en terugkoppeling heeft dit geleid tot hernieuwd onderzoek en is de impedantie plethysmografie als finale test voor de diagnose diepe veneuze trombose inmiddels werlaten.

\section{Besluit}

I k heb tot zover getracht in grote lijnen de "state of the art" en de moge. like ontwikkelingen op het vakgebied van de Klinische Epidemiologie uiteen te zetten. Door de beperking van de tijd heb ik niet het belangrijke onderwerp wan systematisch literatuur onderzoek en meta-analyse kunnen besipreken, doch systematische toepassing van de besproken principes van het meten van therapeutische en diagnastische effectiviteit is, naast het zo volledig mogelijk opsporen van de literatuur, hierbil een belangrijke, zo niet de belangrijkste, eerste stap. Studenten geneeskunde en geneeskundigen in opleiding zullen in de gelegentheid gesteld moeten worden zich de basis principes wan de methodologie wan klinisch onderzoek eigen te kunnen maken, het liefst direct gekoppeld aan de praktijk wan het klinische probleem. Een inquisitieve attitude bij het proces van klinische educatie is hiertoe een vereiste. Stafleden van medische afdelin. gen zouden in staat moeten zijn studenten en assistenten het geneeskun . dige vak bij te brengen met een voortdurende aandacht voor de bewijslast achter het medisch handelen. Stafleden van de capaciteitsgroep Epidemiologie, sectie Klinische Epidemiologie en de afdeling Klinische Epidemiologie en Medical Technology Assessment dienen dit proces te ondersteunen, war nodig het woortouw te nemen. Van nature zal voor deze stafleden het onderzoeksterrein zijh het initiëren, uitvoeren, ondersteunen bij initiëren en witvoeren en, zeker niet in de laatste plaats, het 
methodologisch verdiepen van patientgebonden onderzoek. Door als universiteit deze activiteiten te plaatsen in onderzoeksirajecten die preklinische, klinische en implementatie fasen bevatten, zall de universiteit Maastricht zijn plats in het Europese spectrum van universiteiten kunnen verdienen.

\section{Dankwoord}

Mijnheer de Rector Magnificus, dames en heren, allereerst wil ik het College van Bestuur van de Universiteit van Maastricht, het Faculteitsbestuur Geneeskunde en de Raad van Bestuur van het Academisch Ziekenhuis Maastricht bedanken voor het in mij gestelde vertrouwen.

Het verder betreden van het terrein van het dankwoord is gevaarlijk, met name met het oog op 'false negatives' (onterecht niet genoemde personen). Toch wil ik een aantal personen noemen die voor mijn carrière in de wereld van het patiëntgebonden onderzoek van uitermate groot belang zijn geweest en soms nog zijn. I $k$ zou willen beginnen met het noemen van mijn opleider Interne Geneeskunde, dr. G.J.H. den Ottolander. Hij lag ten grondslag aan het organiseren van een 2 jaar durend verbliff in Hamilton, destijds het mekka van de Klinische Epidemiologie en trombose onderzoek. Aldaar hebben A.G.G. Turpie en J. Hirsh mijn verblijf tot een geweldige persoonlijke en wetenschappelijke ervaring gemaakt. Terug in Nederland ben ik dankzij H.R. Büler, J.W. ten Cate en J.G.P. Tijssen ook hier betrokken geraakt bij het patiëntgebonden onderzoek. Harry, Patrick en Rob, het vertrouwen, de collegialiteit en steun die ik van jullie heb mogen ervaren zijn ongekend. Collegae uit mijn verteden, in het Bergweg Ziekenhuis, Rotterdam, McMaster Clinics, Hamilton, Academisch Ziekenhuis Rotterdam en Academisch Medisch Centrum bij de Universiteit van Amsterdam, dank zij jullie heb ik altijd met plezier kunnen werken en dit werk nimmer als een last hoeven te ervaren. Met plezier denk ik terug aan mijn directe collegae op te KEB en de afdeling Thrombose en Haemostase van het AMC. Een fantastische atmosfeer en een broedplaats van ideeen. De interactie met mijn promovendi tijdens mijn AMC jaren, Paolo, Lieke, Rohan, Bernd-Jan "Gerrit-Jan, Saskia, Barbara, leneke, Jeroen "Hans-Martin Otten "Carlo en Mirjam is altijd een waar genoegen geweest en de wetenschappelijk inhoudelijke discussie uitcagend. Hier in Maastricht, zowel op de capaciteitsgroep Epidemiologie als op de zieken- 
huisafdeling Klinische Epidemiologie en Medical Technology Assessment, ben ik warmhartig ontvangen en ik kijk uit naar de volgende jaren met mijn collegae hier.

Ten slotte mijn familie, Elisabeth, Roeland en Hester. Aanvarkelijk stond de militaire dienst en later het assistentenbestaan, zoals dit was in het begin van de jaren " 80 van de vorige eeuw, participatie in het gezin, zoals dit van een moderne vader verwacht mag worden, in de weg. Nog steeds blink ik niet uit in modern zijn en in het beschermen van mijn priwate tijd. Dankzij jullie lankmoedigheid en bereidheid mij te volgen over de wereld en in Nederland heb ik dit kunnen bereiken.

lik heb gezegd. 


\section{Referenties}

1. Sacket DL, Richardson S, Rosenberg W. Haynes. RB. Evidence - Based Med: cine: Wow to Practice ard Teach EBM. London, Churchill Liwingstone. 2000.

2. Rosendaal Fr. Orat contraceptives and screening for factor $V$ Leiden. Thromb-Maemost, 1996; 75:524-525.

3. Van der Sman I. Mot over mammografie. Elsewer; 13-4-2002, 88-90.

4. Vermeulen $\mathbb{E C}$. Stehowwer CD. Twisk JW, wan den Berg. M. de Jong SC.

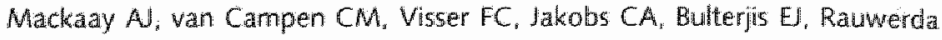
IA Effect of homocysteine-lowering treatment with folic acid plus vitamin B6. on progression of subclinical atherosclerosis: a randomised placebocontrolled trial. Lancet. $2000,355: 517-522$.

5. Kulier PM, Turkstra F, wan Beek E. ten Cate JW. Buller HR. A survey of the diagnostic and therapeutic management of patients with suspected pulmonary embolim in the Netherlands. Netherlands Journal of Medicine 1997; 50: $261-266$.

6. Hagen PI, wan Strijen MU, Kieft GI, Graafsma YP. Prins MH, Postmus PE. The application of autch consensus diagnostic strategy for pulmonary embolsm in clinical practice. Netherlands Journal of Medicine 2001; 59:161-169.

7. Moons KG, wan-ES GA, Deckers IW. Habbema JD, Grobbee DE. Limitations of sersitivity, specificity illkelihood ratio, and bayes" theorem in assessing dim agnostic probabilities: a clinical example. Epidemiology 1997; 8: 12-17

8. Hatky MA, Pryor DB, Harrell FE, Califf RM, Mark DB, Rasati RA. Factors affecting sensitivity and specificity of exercise electrocardiography. Multivariable analysis. American Journal of Medicine 1984; 77:64 71 .

9. Sackett DL, Haynes RB. The architecture of diagnostic research. British Medical Journal 2002; $324: 539-541$.

10. Wells PS, Hirsh J, Anderson DR, Lensing AW. Foster $G_{n}$ Kearon $C$, Weitz I. Cogo A, Prandoni P. Minuk T. Comparison of the accuracy of impedance plethysmography and compression uitrasonography in outpatients with clinically suspected deep vein thrombosis. A two centre paired-design prospective tral. Thromb-Haemast 1995;74: 1423-1427.

11. Anderson DR, Lemsing AW, Wells PS, Levine MW, Weitz II. Hirsh J. Limitationis of mpedance plasmography in the diagnosis of clinically suspected deepvein thrombosis. Annals of Intenal Medime 1993:118:25-30. 


\section{Zeker meten. Zeker weten?}

Medical Technology Assessment als Instrument

Rede uitgesproken bij de aanwaarding vam het ambt van Hoogleraar Medical Technology Assessment aan de Faculteit der Gezondheidswetenschappen van de Universiteit Maastricht op vrijdag 14 juni 2002 door

Dr. I.L. Severens 

Mijnheer de Rector Magnificus,

Geachte dames en heren.

\section{Inleiding}

Vandaag zal ik met het uitspreken wan deze rede het ambt aanvaarden van hoogleraar Medical Technology Assessment. Het feit dat deze leerstoel een Engelstalige naam kent geeft aan waar dit onderzoeksgebied vandaan komt. In de Verenigde Staten werd in de jaren '70 binnen het overheidsadviesorgaan Office of Technology Assessment een programma gestart met het doel maatschappelijke afwegingen te maken ten aanzien van gezondheidszorgprogrammas. De benaming van dit programma, de zogenoemde Medical Technology Assessment lijkt op louter medisch technische interventies te duiden, maar in feite kunnen activiteiten in de gehele breedte van de gezondheidszorg onderwerp van studie zijin, zoals gebruik wan een diagnostische test, het uitwoeren van een specifieke operatietechniek, het gebruik van een geneesmiddel, maar ook het toepassen van een verpleegkundig protocol of het stimuleren van artsen conform een richtlijn te werken. Vandaar dat ook wel wordt gesproken van HTA, of Health Technology Assessment [1]. In het Nederlands zou ik medical of health technology assessment liever willen vertalen in evaluatieonderzoek in de gezondheidszorg, maar inmiddels is de terminologie dusdanig ingeburgerd dat ik in deze rede de afkorting MTA zal hanteren.

\section{MTA in Nederland}

Binnen Nederland werd een aanzet gegeven voor MTA-onderzoek in de jaren ' 80 door het adviesrapport Grenzen aan de groei van het verstrekkingenpakket van de Ziekentondsraad, nu College voor zorgverzekerin. gen geheten. Als belangrijkste instrument voor beslissingen op het macroniveau werd de zogenoemde trechter van Dunning voorgestell. Een medische technologie zou de toet's van noodzakelijkheid, werkzaamheid en doelmatigheid moeten doorstaan woor sprake zou kunnen zijn van opname in het verstrekkingenpakket. Bij het doelmatigheidscriterium, het derde niveau van de trechter, speien kosten van een medische technologie een rol bij de besluitvorming. Met opname in het pakket zou financie- 
ring wan de medische technologie gewarborgd worden. Niet alleen de bestutworming over cen afzonderithe medische technologie zelf, maar ook in relatie tot andere bestedingsaltematieven zou de trechter een rol gaan spelen.

in navolging op deze ontwikkelingen werd in die tijd gestart met de exrste Nederlandse MTA-studies: de evaluaties van hart- en levertransplantatie, de toepassing van In Vitro Fertilisatie en de evaluatie van nationale screening op borstkanker. Op grond van deze studies werd harttransplantatie in het verstrekkingen pakket opgenomen, een nationaal borstkanker screeningsprogramma gestart en worden drie UV pogingen door de zorgverzekeraars vergoed [2]. In het kader van het fonds Ontwikkelingsgeneeskunde werden tussen 1988 en 2000 circa 150 MTA projecten uitgewerd. Het bestaan van dit fonds heeft in belangrijke mate bijgedragen aan de rume evaring die momenteel im ons land bestaat op dit onderzocksterein en waardoor het MTA onderzoek in vergeliking met het buitenland als hoagwaardig kan worden bestempeld.

In mavolging van Australie en Canada werden recent de Nederlandse farmaco economische richtlijnen ontwikkeld [3]. Farmaceutische industrieèn die met een nieuw product een meerwarde claimen ten opzichte wan reeds toegepaste producten moeten vanaf 1 jamuari 2005 niet alleen werkaamheid en veiligheid, maar ook doelmatigheid van nieuwe geneesmiddelen gaan aantonen. Mede op basis van deze kosteneffectiviteit wordt door het Ministerie over opname in het verstrekkingenpakket beslist.

Opvallend is dat binnen hetzelfde Ministerie de opvolger van het Ontwikkelingsgeneeskunde fonds, het huidige Doelmatigheidsfonds dat is ondergebracht bij Medische Wetenschappen van ZorgOnderzoek Nederland (ZonMw), onlangs onder serieuze druk is komen te staan. Kem hier van is dat het weld in tegenstelling tot voorgaande jaren minder mogellikheden krijgt zelf MTA onderzoek te initiëren en financiering hiervoor bij de werbejd an te wagen. Ook het kwalitatief goede Doelmatigheidsprogramma van het College voor zorgverzekeringen en de Vereniging Academische Ziekenthuzen heeft geen vervolg gekregen. Hopelijk betreft deze situatie een tijdelijk staartje van het paarse kabinet want het lijkt Inconsistent om voor nieuwe geneesmiddelen wel en voor andere technologieern in de zorg nict het doelmatigheidsonderzoek te stimuleren c.q. verplicht te stellen. 
De doelstelling van MTA mag uit deze geschiedenis duidelifk ziln: MTA onderzoek beoogt beslissers, zoals de minister van WWS koepels van verzekeraars, instellingsmanagement, maar ook de beroepsgroepen en individuele zorgverleners in de gezondheidszorg te informeren over de voor-en nadelen van het gebruik van technologieèn in de gezondheids zorg. Kortom: Medical Technology Assessment dient als instrument ter onderbouwing van het wel of niet toelaten, bevorderen of daadwerkelijk gebruiken van een medische technologie".

Maar welke informatie is relevant voor beslissers? Want voor-en nadelen wan medisch handelen kunnen zich viten in zeer verschillende aspectien. Niet alleen klinisch resultaat en kwaliteit van leven van patienten zijin van belang, maar ook maatschappelijke aspecten als kosten en juridische, organisatorische en ethische consequenties van gebruik van een technologie kumnen een rol spelen. MTA-onderzoek pretendeert hier nogal wat mee, omdat ze hiermee raakt aan zeer werschillende disciplines en het is onmogelijk voor welke onderzoeker dan ook om alle aandachtsgebieden in detail te dekken. Onderzoek naar de effectiviteit in relatie tot economische aspecten van medische technologie kan als een onmisbaar onderdeel wan MTA worden beschouwd. Ik will me bij de verdere uitwerking van het instrument MTA concentreren op de economische evaluaties oftewel doelmatigheidsonderzoek in de gezondheidszorg [4].

\section{Economische evaluaties en MTA}

De kern van economische evaluaties laat zich eenvoudig omschrijven met de vraag: krijg ik waar voor mijn geld? Met behulp van meestal patiëntgebonden wetenschappelijk onderzoek wordt de relatie expliciet gemaakt tussen kosten en effectiviteit ofwel de behaalde gezondheidswinst voor

\footnotetext{
Dit idee werd recent nog eens bevestigd in de nadere toelichting bij de wijziging van het Verstrakkingenbeslut ziekenfondswerzekeng in verband met het wizigen wan de adanspraak op famaceutische hulp (Staatblad 2002, 242, 29 mei 2002). Herin wordt gesteld dat de eis wan farmacoeconomisch onderoek geen drempel voor ophame wan mieuwe geneesmiddelen in het ziekenfondspakket is. malar just een instrument om geneermiddeten in een pakket van een soctall verakeringsstelsa op te nemer.
} 
patienten. Belangrikste uitkomst van dit onderzoek is dan ook een witspraak over de kosteneffectiviteit, ook wel genoemd relatieve doelmatigheid van een medische technologie. Hierbij wordt expliciet aen vergeliking gemaakt met een altematief, meestal de bestaande situatie. Vervolgens wordt doelmatigheid uitgedrukt in een enkel getal, de zogenatamde incrementele kosteneffectiviteitratio 2 [6]

Zoals uit figuur $\mathbb{1}$ blikkt is een beslissing over deze technologie, hier de kennis en inzet van de dokter, eenvoudig: de technologie kost een stuiver en leverk niks op, waardoor deze technologie als niet-doelmatig kan worden gedefinieerd. Dit geldt in nog sterkere mate als een technologie in vergelijking met een standaard duurder is en tegelijkertijd leidt tot exn lagere patientuitkomst. De medische intenventie is dan ondoelmatig of inferieur. Van dominantie is sprake als een nieuwe medische interventie beter is voor de patient en minder kosten genereert, hetgeen positieve besluitworming eenvoudig maakt. Echter, een afwegingsprobleem bestaat wamneer sprake is van een kosteneffectiviteitratio, die aangeeft dat meer kosten moeten worden gemaakt om een betere patiëntuitkomst te realiseren. En uiteraard komt deze situatie vaak voor, want betere zorg is in de meeste gevallen ook duurdere zorg.
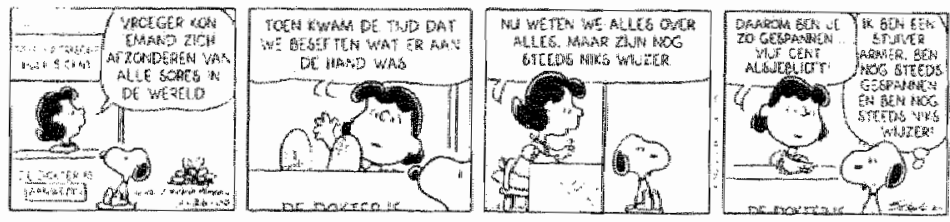

Figuur 1. De kosteneffectiviteit van medisch handelen

Eém van de doelstellingen van economische evaluaties in de zorg is hef onderling vergelijkbaar maken van de doelmatigheid van medische technologieern. Gebruik wan medische middelen en inzet van zorgverleners worden makkelijk in monetaire eerheden als euro's en dollars utgedrukt. Moeilifker is het on de resultaten van medisch ingrijpen wit te drukken in een algemeen getal. Relatief eenvoudig en vergelijkbaar tussen verschil-

2 Ahoewel de incrementede kosteneffectriteitratio eenvoudig te berekenen is, wordt dit getal inakikelijk verkeend geinterpreteerd $15 !$ 
lende aandoeningen kan de levensverwachting van patienten als uitkomstmaat worden gehanteerd en kan de kosteneffectiviteit van ingripen worden uitgedrukt als kosten per extra levensjaar. Hierdoor kan de doelmatigheid van harttransplantatie met cholesterol verlagende medicinen worden vergeleken. Niet al het medisch ingrijpen leidt tot verandiering in levensverwachting; maar in dat geval kan ook verandering in de gezondheidstoestand van patiënten relevant zijn, uitgedrukt als de verandering in kwaliteit van leven. Gerelateerd aan de levenswerwachting van patiènten, leidt dit tot de veelgebruikte witkomst kwaliteit gecorrigeerde levenswerwachting, ofwel Quality Adjusted Life Year (QALY). Met een dergelijke algemene uitkomst van onderzoek is eenvoudig een lijst samen te stellen, waarbij een volgorde van aflopende doelmatigheid wordt gehanteerd ${ }^{3}$. Dan kan simpelweg bekeken worden of een nieuwe medische technologie wel met stip in de top tien binnenkomt, om zodoende vergoeding door verzekeraars of toestemming door instellingsmanagement af te dwingen.

\section{Zekerheid binnen economische evaluaties}

Maar de vraag is of een schijnbaar gunstige kosteneffectiviteitverhouding, zoals wit een dergelijke QALY tabel blijkt, wel zekerheid biedt. Zoals eer* der aangegeven is de uitkomst van een doelmatigheidstudie een getal, de kasteneffectiviteitratio. En om een dergelijk getal begrijpelijk te maken kan deze worden weergegeven in een kosteneffectiviteitgrafiek. In figuur 2 wordt van de alternatieven het effectverschil (weergegeven op de $x$-as) gerelateerd aan het kostenverschill (weergegeven op de $y$-as). Hierin staan de gebieden aangegeven die dominantie (dus in vergelijking met een alternatief goedkopere en betere technologie) dan well inferioriteit weergeven, omdat, zoals eerder aangegeven, deze tot een eenvoudige beslissingleiden.

Als woorbeeld geldt hier de uitkomst van een onderzoek naar behandeling wan patiëthten met het chronisch vermoeidheidsyndroom, die, ofwell conm form huidige standaard behandeld werden, dan wel cognitieve gedragstherapie als experimentele behandeling hebben ondergaan. Als uit. komstmaat werd het al dan niet hersteld zijn van chronische vermoeid.

In de Engeistalige literatuur wordt een dergeligke tabel OALY-league table genoemo 
heid 14 maanden na aanwang van therapie gehanteerd. Zoals met een sterretje in de grafiek aangegeven liet de berekening van de doeimatigheid een eenvoudig beeld zien: de experimentele strategie leidde in ver gelijking met de huidige behandelingsmethode tot lagere kosten en hogere effecten, uitgedrukt in de proportie patienten dat was hersteld. De keuze leek eenvoudig: bij lagere kosten en hogere effectiviteit is sprake van dominantie en dus leek de experimentele behandeling zonder twijfel ingewoerd te moeten worden.

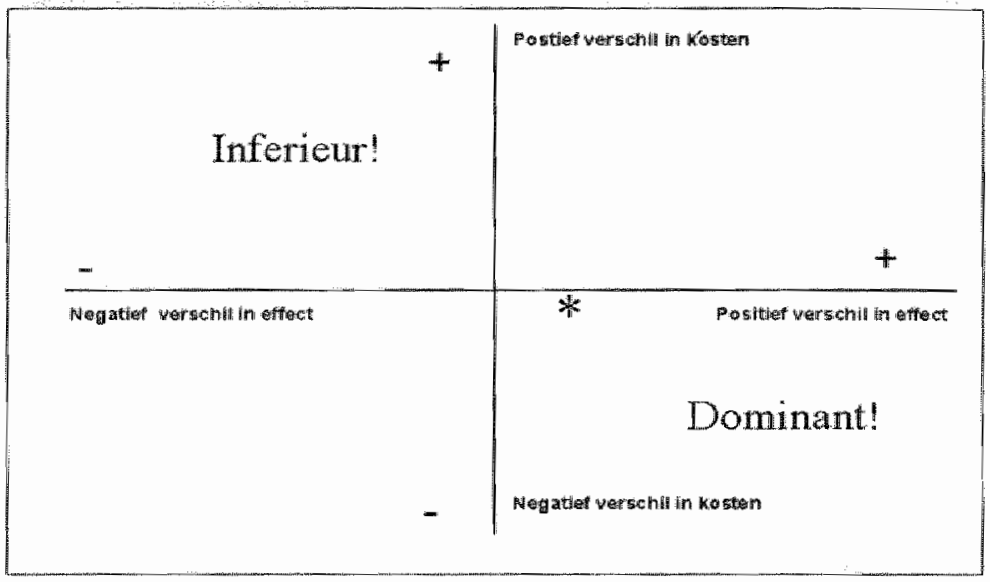

Figuur 2. De kosteneffectiviteitgrafiek

Nu was deze kosteneffectiviteitratio gebaseerd op een relatief kleine groep patiënten. En kortweg: hoe kleiner een groep patiënten in een dergelijk onderzoek, des te groter de statistische onzekerheid van de kosteneffectiviteitratio. Gangbare statistische methoden om de zekerheid van verschilien tussen patiëntengroepen aan te geven zijn niet bruikbaar bif een ratio van twee getallen, in dit geval kosten en patientuitkomsten. Een aplossing hiervoor is, op basis van een steekproef van de patiéntgegevens, vele malen herberekenen van de kosten en effecten, waardoor bijwoorbeeld 1.000 kosteneffectiviteit ratio's ontstaan. Deze techniek wordt bootstrapping genoemd [7]. 


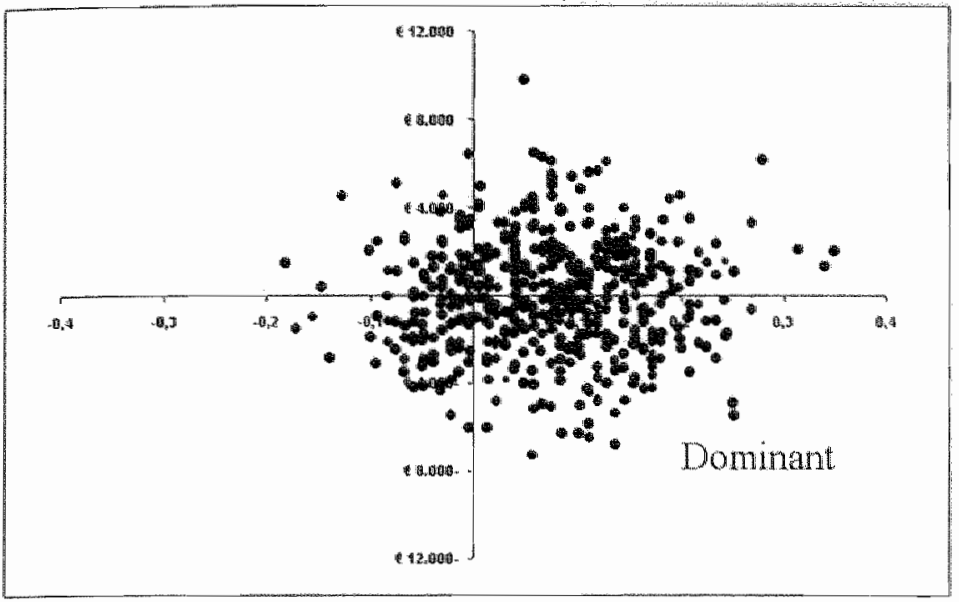

Figuur 3. Resultaat van 1.000 bootstrap simulaties.

Uit de ligging en de compactheid van de puntenwolk wordt dan duidelijk in hoeverre onderzoeksuitkomsten zeker zijn. In dit onderzoeksvoorbeeld bleek dat de weronderstelde dominantie in slechts $38 \%$ van de simulaties werd bevestigd. Dit specifieke onderzoek leverde niet de gewenste zekerheid op ten aanzien van de kosteneffectiviteit van de behandeling. In een dergelijk geval kumnen analyses vam subgroepen aangewezen zijn [8].

Een andere situatie betreft doelmatigheidsonderzoek naar orthodontische behandeling van schisiskindjes. Hier geeft de kosteneffectiviteit, uitgedrukt in een spraakscore op 2,5 jarige leeftijd, zo goed als zeker aan dat altijd sprake is wan een betere patiëntuitkomst, maar dat daarvoor met aan zekerheid grenzende waarschijnlijkheid hogere kosten noodzakelijk zijn (zie figuur 4). Met behulp van het definièren van een minimaal gewenste verbetering van een patient en een maximum bedrag dat beleidsmakers bereid zijn hiervoor te betalen (zoals eerder genoemd de kosten per Quality Adjusted Life Year of anders de kosten per succesvol behandelde patient) kan berekend worden wat de statistische kans is dat op basis van dit onderzoek de kosteneffectiviteitverhouding acceptabel is. in het geval wan een fictief doelmatigheidsplafond, bijvoorbeeld een maximale betalingsbereidheid of willingness to pay van 750 . - per punt. verbetering op de spraakscore is die kans het percentage ratioschattingen 
dat rechts van de grenslijn ligt, namelijk $60 \%$. Alhoewel nu de maximale investering per eenheid gezondheidswinst bekend is, is nu nog geen rekening gehouden met de totale budgettaire consequenties van positieve besluitvorming. Want, alhoewel de investering per eenheid behaald effect laag kan zijn, kan dit macrobudgettair, als gevolg van een zeer grote groes patienten, de nodige financiêle consequenties hebben. Het lijkt dus onmogeifik een algemene beslisregel met betrekking tot doelmatigheid van medische technologieen te definieren, omdat dit onder meer zou leiden tot een miet te remmen groei van de kosten van de gezondheidszorg in Nederland. Een gunstige kosteneffectiviteit van een nieuwe technologie biedt dan ook geen absolute zekerheid. Vandaar dat beshissingen op basis van de kosteneffectiviteit van een medische interventie ondersteund moeten worden door een inschatting van de budgetimpact van een toelating tot de zorg of tot invoering in een instelling.

\section{Budigetimpact analyse}

Een dergelijke budgetimpact analyse maakt expliciet wat de gevolgen zijn wan een positieve beslissing ten aanzien van de invoering van een medische technologie in de Nederlandse gezondheidszorg. Het is hievoor noodzakelijk, naast de investeringen en mogelijke besparingen op patiëntniveau die uit het doelmatigheidsonderzoek blijken, te weten hoeveel patienten woor de onderzochte diagnostische of therapeutische methode in aanmerking komen en hoe deze patiënten tot op dit moment gediagnosticeerd of behandeld worden. Hiertoe dient de omvang van de patiëntenpopulatie omschreven te worden. hetgeen uitgedrukt wordt in typisch epidemiologische kengetallen als de prevalentie en incidentie van de aandoening. Na vermenigvuldiging van de cijfers op patiẻntniveau, met de cijfers op populatieniveau kunnen onderzoekers beleidsmakers duidelikk maken welke totale kosten door inwoering van de medische technologie gegenereerd worden. 


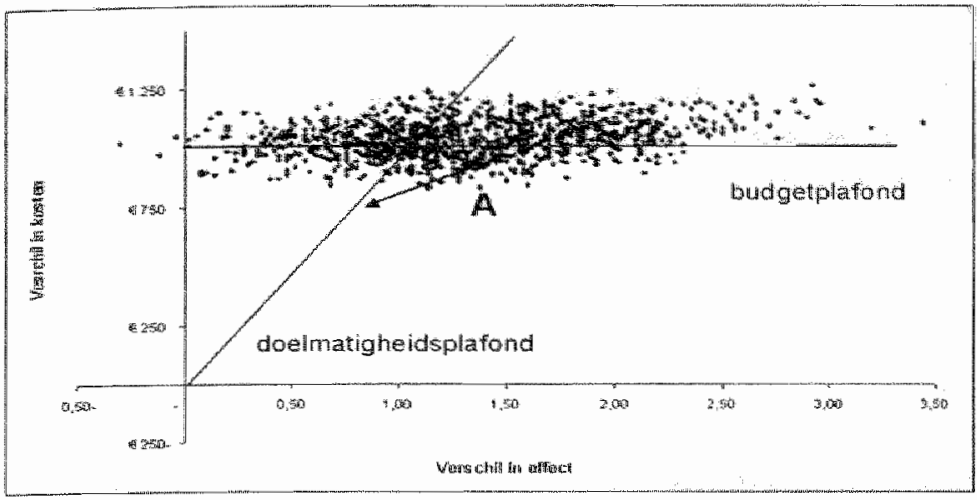

Figuur 4. Ratio-onzekerheid in relatie tot het doelmatigheidsplafond en budgetplafond.

Deze benadering gaat uit van maximale budgettaire ruimte, iets dat, gezien het feit dat de kosten van de zorg niet onbeperkt mogen groeien. een utopie is. In het geval van een vastgestelde totale budgettaire ruimte is het mogelijk de maximale budgettaire ruimte per patiënt te bepalen. Dit patiëntbudget, hier gesteld op $€ 1.000$, - kan gecombineerd worden met de relatieve doelmatigheid van een nieuwe medische technologie, door een plafond te stellen in de extra investering voor de behandeling van een patiënt. De onzekerheid van de kosteneffectiviteit van een medische technologie, zoals weergegeven kan worden door de puntenwolk, wordt nu nogmaals verdeeld. Naast de indeling acceptabele en niet-acceptabele kosteneffectiviteitverhouding, ontstaat de indeling budgettair mogelijk en budgettair onmogelijk [9]. De hoogte van het percentage kosteneffectiviteitschattingen dat binnen beide grenzen valt, hier weergegeven door het gebied A, geeft aan in welke mate zeker is gemeten en we tegelijk ook zeker weten. U kunt zich voorstellen dat een geneesmiddel of een opera tietechniek zou kunnen voldoen aan een doelmatigheidseis, maar als de

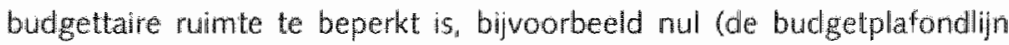
zou gelijk vallen met de $x$-as van de grafielk), de beslissing over toepassing toch negatief wordt.

Het mag daarmee duidelijk zi]n, dat beslissingen en prioriteitstelling op basis van eerdergenoemde doelmatigheidshitparade voor cen doelmatige zorg niet wenselijk is en dat het zekere voor het onzekere moet worden 
genomen. U begrijpt dat ik hier een belangrijke laak voor MTA onderzoekers zit. In het kader van specifieke kosteneffectiviteitstudies moet meer inzicht worden verkregen in zowel doelmatigheidsplafond als budgetplafond. Belangrijk hierbij is om steeds vast te stellen wie wat met de resultaten wan ons soort onderzoek moet gaan doen: overheid, verzekeraar. instelling of afdeling.

\section{Modellering in economische MTA}

Echter, kunnen we alleen zeker weten als er zeker is gemeten? Dit zou inhouden dat beslissingen betreffende medische technologieèn uitgesteld moeten worden tot werkelijk voldoende empirisch bewijs verzameld is om de doelmatigheid en eventueel bijbehorende budgetimpact precies te kunnen aangeven. Als voorbeeld van dit dilemma zal ik (eerdergenoemde) screening van darmkanker toelichten. Nu is reeds bekend dat de sterfte aan darmkanker, jaarlijks zo'n 4.000 personen, tegen geringe kosten met één viffde omlaag kan als personen ouder dan 50 jaar hiervoor regelmatig onderzocht worden. Nu resteert de vraag welke screeningmethode het beste gehanteerd kan gaan worden: louter ontlastingsonderzoek of screening met behulp wan een endoscopische camera waarmee direct in de darm kan worden gekeken? Voordeel van deze techniek ten opzichte van het ontlastingsonderzoek is het feit dat poliepen, die mogelijk wijzen op een woorstadium van kanker, direct verwijderd kunnen worden. Om hier een keuze in te maken wordt momenteel een wetenschappelijk onderzoek overwogen. Dit onderzoek zal naar verwachting over 10 jaar een antwoord geven en 20 miljoen euro gaan kosten.

Echter, inmiddels is als gevolg van vrijwillige screening op darmkanker en door opgedane envaring in het buitenland reeds veel bekend over effectivteit con kosten van screeningmogelijkheden. Vraag is dan ook of we 10 jaar moeten wachten om zeker te zijn welk screeningprogramma het beste in te voeren is of om op basis van de reeds bekende gegevens. de doelmatigheid van verschillende screeningstrategieen in te schatten. Expliciteren van analyse-en berkeningsmethoden is dan een vereiste. Belangrijk hierbil is vast te stellen welke onderdelen van het voorspellingsnodel bepalend zijn voor de onzekerheid van de doelmatigheidsuitkomst. Mede op basis hiervan kan nader empirisch onderzoek worden 
gedefinieerd dat bijwoorbeeld bestaat uit longitudinale follow-up van patienten, hetgeen een typisch epidemiologische opzet is [10]. Het is evident dat ten behoeve van doelmatigheidsmodellen maar ook ten behoeve van zogenaamde kosten van ziektenstudies verzameling van kostengegevens een standaard onderdeel van dergelijk abservationeel onderzoek moet zijn.

Ik werwacht dat doelmatigheidsmodellen een steeds belangrijkere rol gaan spelen bij keuzen in de zorg. Academische centra en daaraan verbonden MTA onderzoeksgroepen kunnen zich profileren door het ontwerpen wan ziektemodellen en het op een gestandaardiseerde manier verzamelen van gegevens daarvoor. Op die manier kan economisch MTA onderzoek makkelijker als instrument bij actuele beleidsproblemen een rol spelen.

\section{Beperkingen}

Maar zelf́s als bij een beslissing op basis van doelmatigheid van een medische interventie op zeker wordt gespeeld, zijn er aspecten die niet of nauwelijks in doelmatigheidsonderzoek en in de daaruit resulterende indicatie voor kosteneffectiviteit en budgetimpact expliciet worden belicht.

Ten eerste betreft dit financieringsschotten binnen en tussen instellingen in de zorg, maar daarnaast ook tussen verschillende maatschappelijke sectoren. Bij de economische evaluatie van zorgalternatieven in een ziekenhuis in vergelijking met zogenaamde transmurale zorg wordt verschuiving van budgettaire ruimte van intramurale naar extramurale zorg verondersteld, terwijl dat in de huidige financieringspraktijk niet zo cenvoudig ligt. Maar ook binnen instellingen kunnen financieringsschotten een belemmerende rol spelen. We kunnen bijwoorbeeld vaststellen dat het doelmatig is om met behulp van MRI diagnostiek onnodig opereren bij prostaatkankerpatiënten te voorkomen [11]. Maar om daadwerkelijk de zorg op die manier toe te passen zou budgettaire ruimte van uroloog naar radioloog moeten verschuiven, hetgeen vooralsnog niet eenvoudig blikt. Maar ik verwacht dat de nieuwe financieringssystematiek op basis van Diagnose BehandelingsCombinaties hier een belangrijke impuls zal zijn. De voorsprong die Maastricht in het hieraan gerelateerde terrein van de Diagnosis Related Groups (DRG's) heeft zal hierbij een voordeel zijn in toekomstig MTA onderzoek. 
Kostenbespang in bedrijuen en bif sociale verzekeraars door verminderd arbeidsverzuim als gevolg van effectieve medische behandeling is voor verschillende aandoeningen zoals migraine aangetoond [12]. Budgetwerschuivingen tussen ministeries onderling zijn in dat geval noodzakelijk on theoretische doulmatigheid praktisch te realiseren maar deze lijken vooralsnog moeilijk te realiseren. Kortom we zullen met de berekening van doelmatigheid meer rekening moeten gaan houden met financieringsschotten binnen en buiten de zorg on zo economisch MTA onderzoek beter als instrument te kunmen gebruiken.

Maar darnaast bijuen er, zoals ik in de inleiding aangaf, aspecten gerelatererd aan medisch handelen die geen onderdeel zijn van de economische invuling wan MTA onderzoek, maar die wel degetijk van belang moeten zijn bij beslissingen omtrent invoering en toepassing van medische technologie. Dit wordt ook wel omschreven als de brede invulling van MTA onderzoek. Het is onmogeligk alle aspecten van medische technologie in een enkele leerstoel, laat staan in een enkele persoon te verenigen. Daarom vind ik nauwe samenwerking met andere onderzoeksgroepen binnen en buiten deze universiteit belangrijk.

\section{Conclusies van de rede}

In het voorgaande heb ik u willen laten zien dat woor mij economisch MTA onderzoek pas zinvol is als de resultaten daarvan mede van invloed zijh op de inrichting van de gezondheidszorg in Nederland. As Nederlan. ders zijn we zeer kritisch over de gezondheid van onze zorg. Zo heeft demissionair Minister Borst eergisteren nog erkend dat door de wachthijsten mogelik patienten onnodig overliiden. Toch wordt daar in het buitenland anders tegen aangekeken: in een recent artikel in The Economist wordt beschrewen dat in vergelijking met de andere OECD landen onze zorgeen hoge kwaliteit kent en dat de gezondheidssituatie van de bevol. king hoog is, terwijl relatief weinig geld a an zorg wordt besteed [13]. Maar er wordt daamaast opgemerkt dat beperkle beschikbaarheid van medisch personeel en een strikte budgettering heeft geleid tot de bekende wachilistproblemen en onbeantwoorde zorgvraag.

Keuzen in de zorg blijven dan ook noodzakelijk en daarom verwacht ik dat economische MTA in de toekomst een belangrijker rol gaat spelen. Zo zullen farmaceutische industrieën nieuwe geneesmiddelen moeten 
ondemerpen aan de doelmatigheidseis. Daarnaast is de verwachting dat prioriteiten in de zorg niet meer hoofdzakelijk door de centrale overheid vastgesteld gaan worden. In het kader van de nieuwe financieringsstructuur die op handen is, zullen verzekeraars vergoedingen moeten vaststellen en mee willen beslissen over de feitelijke inhoud wan behandelstrategieën. En in voorbereiding hierop moeten (koepels van) instellingen en zorgverleners de bewijzen en argumenten overleggen welke zorg voor pattënten, binnen welke financiële grenzen, mogelijk is. In het kader hierwan wordt ook wel gesproken over het zelfregulerend vermogen van de zorg en de kanteling van de eerdergenoemde trechter van Dunning [14].

In het kader wan deze ontwikkelingen is mijns inziens dus een explicie. te rol woor economisch MTA onderzoek weggelegd. (Ik) verwacht daar geen wonderen wan, in de zin dat de resultaten dergelijk onderzoek directief gebruikt zullen worden. Veel meer dient ons onderzoek als imstrument ter ondersteuning van besluitvorming over medische technologie [15]: MTA onderzoek kan dus alleen echt zinvol zijn ais onderzoekers zich realiseren welk besluit op basis van onderzoeksgegevens door wie genomen dient te worden. De ontwikkeling van de methodologie van economisch MTA onderzoek heeft zich de afgelopen jaren vooral gericht op het aspect zeker meten. Alhoewel er natuurlijk altijd aspecten in dat kader te onderzoeken blijven, is ruime ervaring opgedaan hoe kosten en effecten in termen van patiëntuitkomsten valide en betrouwbaar gemeten kunnen worden. Meer dan nu het geval is zal MTA onderzoek zich echter moeten gaan richten op zeker weten, door enerzijds aan te geven waar onzekerheid van doelmatige technologie door bepaald wordt; anderzijds is meer kennis van eerdergenoemde doelmatigheidsplafond en budgetplafonds noodzakelijk om beslissers op zeker te kunnen laten spelen.

Zoals in de inleiding aangegeven raakt MTA hierbij andere disciplines. Diagnostische technieken en therapeutische mogelikheden zullen onderwerp van MTA onderzoek bljwen en samenwerking met de Klinische Epidemiologie is daarom een vereiste. Maar daarnaast verwacht ik dat specifiek medisch handeten eveneens in het kader van de totale zorg rond patięnten economisch zal moeten worden geëvalueerd. waarmee deze leerstoel aan tafel zit met de leerstoelen Kwaliteitsbevordering en . bewaking in de Huisartsgeneeskunde. Eerste- en tweedelins Zorg voor Chronisch Zieke Patiënten, en Logistiek en Operationeel Management in de Zorg. Wat betreft ontwikkeling van onderzoeksmethoden zie ik raakpunten met de disciplines Economie van de Gezondheidszorg en Medi- 
sche Statistiek. Daanaast zie ik belangrijke samenwerking weggelegd met onderzoekers binnen Huisartsgeneeskunde en het Transmuraal Diagnoslisch Centrum en afdelingen binnen het AZM waar de afdeling KEMTA reeds intensieve contacten onderhoudt, waaronder bijvoorbeeld de afdelingen Interne Geneeskunde, Radiologie, Gynaecologie. Psychiatrie en Medische Psychologie. Zeker MTA anderzoek staat of valt mijns inziens met een goede samenwerking met clinici.

Maar naast onderzoek speelt onderwijs een rol in mijn leeropdracht. De vraag op de arbeiosmarkt naar afstudeerders met MTA onderzoeksbagage is groter dan het aanbod en hier ligt mijns inziens een belangrike taak. Tijdens de bachelorfase van het nieuwe onderwijsprogramma moeten alle gezondheidswetenschappen studenten te weten komen wat economisch MTA onderzoek is en waarom dit ook voor beleidsmakers op macrom, meso- en zelfs ook microniveau belangrijk kan zijn. Door deze kennismaking geinteresseerd geraakte studenten moeten zich in de Masters fase voldoende kunnen profileren door het volgen van onderwis, dat zich richt op de opleiding van kwantitatief goed onderlegde onderzoekers. Hier zie ik belangrijke mogelijkheden om samen met de klinische Epidemiologie zowel binnen gezondheidswetenschappen- als binnen geneeskunde studenten op te leiden. Daarnaast zou voor geïnteresseede studenten binnen de economische faculteit zowel gezondheidseconomie als economische MTA meer aandacht verdienen; een punt dat mu reeds aandacht heeft van de leerstoelhouder Gezondheidseconomie en mijzelf.

Buiten deze universiteit spelen eveneens een aantal MTA onderwilszaken waar ik taken zle weggelegd. De Nederlandse Vereniging voor Technology Assessment in de Gezondheidszorg (NVTAG) heeft sinds haar oprichting in 1996 haar bestaansrecht, door tal van activiteiten, waargemaakt. Als bestuurslid van deze organisatie heb ik me actief bemoeid met scholing van jonge Nederlandse MTA onderzoekers, een taak die ook door onze demissionaire minister aan deze vereniging wordt toebedeeld. Ik neem mij dan ook voor het nationale en intermationale netwerk en de onderlinge contacten van (jonge) MTA onderzoekers te intensiveren, onder andere door het organiseren van wetenschappelijke bijeenkomsten. 
Mijnheer de Rector Magnificus, dames en heren, ik wil besluiten met het dankwoord van mijn rede. Mijn leerstoel is het resultat van een gezamenlijke inspanning van de Raad van Bestuur van het Academisch Ziekenhuis Maastricht, het College van Bestuur van de Universiteit Maastricht, de Faculteit der Gezondheidswetenschappen en de Faculteit der Geneeskunde. Zonder iedereen met naam en toenaam te noemen, wil ik graag de betrokkenen binnen deze instellingen bedanken voor het in mij gestelde vertrouwen. De benoemingscommissie van deze leerstoel heeft zich van haar progressieve kant laten zien door akkoord te gaan met mijn wekelijkse vaderdag. Ik hoop hiermee mijn steentje te hebben bijgedragen aan een barst in het academische glazen plafond. De zeergeleerde heer Carpay en de hooggeleerde heren Knottnerus. Spreeuwenberg en Van Schaijck dank ik voor het feit dat ze mij met hun persoonlijk vertrouwen over de streep hebben kunnen trekken. Ook mijn medeorator Martin Prins dank ik in dit kader.

De. basis van mijn interesse voor het doen van economisch MTA onderzoek werd gelegd tijdens mijn Beleid- en Beheerstudie aan de universiteit Maastricht, vooral door mijn student-assistentschap bij de toenmalige vakgroep Economie van de Gezondheidszorg, onder leiding vain professor Frans Rutten. Het doet me deugd dat mijn bazen van die tijd, de toen gepromoveerde en inmiddels hooggeleerde heren Eddy van Doorslaer en Richard Janssen, nu hier in vol ornaat aanwezig zijn. En alhoewel ik na mijn afstuderen verschillende werkgevers in de zorg heb gekend, variërend van een Nederlandse zorgverzekeraar tot Artsen zonder Grenzen in Afrika, zijn de onderzoeksinteresse en -vaardigheden pas echt ontwikkeld in mijn Nijmeegse periode. Pieter de Vries Robbé, Gert Jan van der Wilt en Paul Krabbe, zeer bedankt voor de jaren dat we samen hebben gebouwd aan de MTA afdeling van het UMC St.Radboud. Deze jaren zijn voor mijn onderzoek-en onderwijservaring bepalend geweest. Uiteraard was dit alles niet voorspoedig gegaan zonder de goede samenwerking met de clinici aldaar, waarvoor dank.

Tijdens mijn verkennende missie hier in Maastricht werd ik aangenaam verrast door de prima kwaliteit en goede sfeer bij de afdeling KEMTA. Niet één, maar zelf́s twee nieuwe leerstoelhouders en daarnaast een echt afdelingssecretariaat hoeft in een bloeiende afdeling riet per definitie goed te vallen. Voor jullie positieve houding en prettige ontvangst dank ik 
dE KEMTA medewerkers. Ik zal mijn best doen voor een stimulerende en prettige werkomgeving.

De capaciteitsgroep Beleid Economie en Organisatie van de Zorg $(B E O Z)$ is min onderkomen voor de andere heift van mijn werkweek. Binnen deze groep voorzien voomamelijk de hooggeleerden Wim Groot, Hans Maarse en Frits van Merode mil van raad. Voor daad dank ik de mensen van het secretariat, in het bijzonder Peggy Peeters, die, ondanks hatur initiel verbazing dat ik aanspraak op haar tijd maakte, voor mij onmisbaar is. Maar daarnaast dank ik ook de overige personen van het ondersteunend en beherend personeel. Binnen BEOZ hoop ik, meer dan tot nu toe het geval is geweest, samen met de onderzoekers op dit terrein aan de MTA kar te gaan trekken.

Lieve pap en mam, het feit dat ik hier sta dank ik voor het belangrijkste deel aan jullie. Mijn koppigheid werd resoluut in de kiem gesmoord toen ik thet echt zall was op het WWO en er de bruil aan wilde geven. En de kans die jullie me gaven om er zelf achter te komen dat de edelsmederij een prachtig ambacht is, maar niet echt bij me past heeft me meer dan gemiddeld gemotiveerd om serieus te studeren. Ook nu zilin jullie nog steeds bereid als klankbord te dienen bij lastige keuzen, alhoewel ik moet toegeven het boek van Quitilianus nog niet gelezen te hebben. Kortom, als shirtreclame hier zou zijn toegestaan zou ik jullie namen op de mouwen van mijn toga dragen!

Dank aan jullie maar ook aan mijn schoonfamilie voor het vullen van de gaten die soms in mijn vadertaken vallen omdat ik weer zo nodig iets voor mijn werk niet kan laten of om gewoon naar de fiim of de sauna te kunnen gaan. Dank aan overige familie en wrienden voor de geboden gezelligheid en het onbewust relativeren van mijn wakbeperktheid. Alhoewel er sinds mijn studententijd in Maastricht minder tijd vrij is, zullen speleologen en hardlopers er woor moeten zorgen dat mijn nieuwe status en de daarbii behorende mores geen te grote belemmering vormen om af en toe nog leuke dingen te doen. Nog steeds dank ik de Nijmeegse, maar inmiddels ook de Maastrichtse harcloopcollega's voor de ontspanning tijderis de inspannende duurlopen en sinelle kilometers.

Als laatste ben ik dan uiteindelik bij het thuisfront aangeland. Robbe zelf kan nog niet begrijpen hoe bijzonder het yoor me is als hij zoals altijd vol energie hartelijk schaterlacht of met zijn armpjes wijd op me af komt rennen. En, zeker weten als belangrijkste, Anita, iij...

ik heb gezegd. 


\section{Referenties}

1. Raad woor Gezondheidsonderzoek, Rapport wan het platform HTA: stimulering HTA in Nederland. 2001, RGO: Den Haag.

2. Boer A. Assessment and regulation of heath care techologie: the Dutch experience. International loumal of Technology Assessment in Heath Care. $1999 ; 15: 638-648$.

3. Riteco JA, Heil LMd, Luin ICFV, Wolff I, Richtlinen voor farmaco economisch onderzoek 1999, College voor zorgverzekeringen (CVZ): Amsteween.

4. Drummond MF. O'Brien B). Stoddart Cit. Torrance GW, Methods for the economic evaluation of health care programmes. 2 ed. 1997, Oxford: Oxford Medical Publications.

5. Doubilet PM. Weinstein MC. MCNeil BJ. Use and misuse of the term cost effective' in medicine. New England Joumal of Medicine, 1986:314:253-255.

6. Johannesson $M$. On the estimation of cost-effectiveness ratios. Health Policy, 1995: $31: 225-229$.

7. Briggs AH, Wonderling DE. Mooney CZ. Pulling cost-effectiveness analysis up by its bootstraps: a non-parametric approach to confidence interval estimation. Health Economics, 1997:6:327-340.

8. Briggs AH. Using cost-effectiveness information. British Medical Joumal, 2000; $320: 246-246$.

9. Sendi PP. Briggs AH. Affordability and cost-effectiveness: decision-making on the cost-efrectiveness plane. Health Economics, 2001: 10:675-680.

10. Black WA. Why we need observational sudies to evaluate the effectiveness of health care. British Medical Joumal, $1996 ; 312: 1215-1218$.

11. Jager GJ, Severens JL, Thornbury JR, Rosette UdH, Ruijs SHJ, Barentsz JO. Prostate cancer staging; should MR imaging be used? A decision analytic approach. Radiology, 2000; $215: 445-451$.

12. Roilen LW, Essink-Bot: M-L, Koopmanschap MA. Michel BC, Rutten FHH. Societal perspective on the burden of migraine in The Netherlands. PharmacoEconomics, 1995; $7: 170-179$.

13. Peet A. A survey of the Netherlands. The Economist, 2002.

14. Muder HH. Duming gekanteld. Medisch Contact, 1997: 52: 1219-1220.

15. Shadish WR, Cook TD, Leviton LC, Foundations of program evaluation. 1991, London: Sage Publications. 